\title{
Inclusive Pedagogy Literacy among Academic Community at Institute of Teacher Education, Kuala Lumpur
}

\author{
Munira Mohsin'1, Abd Razak Zakaria ${ }^{2}$ \\ ${ }^{1}$ Institute of Teacher Education (Ilmu Khas), Kuala Lumpur, Malaysia \\ ${ }^{2}$ Department of Educational Foundation and Humanities, Faculty of Education, University of Malaya, Kuala Lumpur, Malaysia \\ Email: munira@ipgkik.edu.my, abdrazak@um.edu.my
}

How to cite this paper: Mohsin, M. and Zakaria, A.R. (2017) Inclusive Pedagogy Literacy among Academic Community at Institute of Teacher Education, Kuala Lumpur. Open Journal of Social Sciences, 5, 114-122. https://doi.org/10.4236/jss.2017.52011

Received: January 10, 2017

Accepted: February 11, 2017

Published: February 14, 2017

Copyright (c) 2017 by authors and Scientific Research Publishing Inc. This work is licensed under the Creative Commons Attribution International License (CC BY 4.0).

http://creativecommons.org/licenses/by/4.0/

\section{(c) (i) Open Access}

\begin{abstract}
This study aimed to explore Inclusive Pedagogy Literacy among the academic community at the Institute of Teacher Education (Institut Pendidikan Guru). The focus of the study is the application of Inclusive Pedagogy in teaching and learning in the classroom. The samples were chosen among the lecturers at the Institute of Teacher Education through purposive sampling based on their involvement in their major teaching specialization for the subject of special education, language specialization, music studies, physical education and sports science, Islamic education and visual arts education. Qualitative methods involving interview techniques, observation and reflection of teaching have been fully utilized in data collection. Data were analyzed by inductively to get the theme in line with the objectives of the study. The findings showed that the elements such as the ability of students, provision of equal learning opportunities, the active involvement of students, and the diversity of students' capability are the themes to taking into account by the respondents. Implications of the findings of the study suggest that the inclusive pedagogy literacy among the academic community is in a position to provide added value to students' knowledge. Awareness of inclusive pedagogy will help in preparing students as a novice teacher to be able to formulate a coherent activity based on clinical experience and effective teaching.
\end{abstract}

\section{Keywords}

Literacy, Inclusive Pedagogy, Academic Community, Teacher Education

\section{Introduction}

The teacher education curriculum in Malaysia is a plan designed to give learning experience for learning and learning experience for teaching. This is aimed at 
producing professional teachers who are dynamic, relevant, futuristic, responsive, holistic, and integrated (Ministry of Education Malaysia, 2013) [1]. The curriculum is a comprehensive plan to be inculcated in the future teachers through the implementing agents in Institute of Teacher Education or known as Institut Pendidikan Guru (IPG). In this context, the Institute of Teacher Education (Institut Pendidikan Guru) plays a role in delivering knowledge, training and equipping future teachers in various fields to fulfill the needs of education in Malaysia in line with the needs of the current globalization concept.

The role of IPG's in enhancing the effectiveness of the education system to a global excellence level on par with other developed countries is recognized by the world; its mission requires very high expertise and skills among lecturers. The expertise and skill that are enhanced from time to time are aligned with the rapid developments in research as seen in various new scenarios such as changes in teaching and learning strategy implemented in the classroom. The movement based on the National Education Philosophy (Falsafah Pendidikan Kebangsaan or FPK) is designed to transform education in a systemic way in terms of school learning practice and school management toward preparing students to face the era of knowledge explosion without borders and simultaneously facilitate 21 st century learning (Ministry of Education Malaysia, 2013) [1].

\section{Inclusive Pedagogy and Academic Community}

Pedagogy is the art and science of teaching encompassing principles, strategies, approaches and techniques and various considerations to ensure the success of any teaching (Cohen \& Bhatt, 2012) [2]. Such teaching is said to be an art and a science because it needs to take into consideration individual differences among students, to select the appropriate approach, meet the students' needs and consider the students' potential. These elements are necessary for equipping future teachers so that they are ready when assigned as novice teachers in schools later (Lumpkin, Achen, \& Dodd, 2015) [3].

Inclusive Pedagogy (IP) forms one of the teaching media where this pedagogy practice can fulfill the varied needs and different capacities of student groups (Milem, 2007) [4]. The practice of Inclusive Pedagogy in the classroom is one of the initiatives proposed to achieve the government's aim of enhancing equity and unity. The aim is highlighted in the Malaysia Education Blueprint (MEB) 2013-2025 (Ministry of Education Malaysia, 2013) [1]. Studies show that IP is able to create an environment unlimited by student diversity in terms of cognitive level, and social and cultural backgrounds (Cohen \& Bhatt, 2012; Florian \& Spratt, 2013) [2] [5].

The academic community in a tertiary institution plays a role as a model for students (Bocala, 2012) [6]. They also act as catalysts in encouraging higher order thinking skills, creativity, innovation and building self concept in activating the learning process in line with the current curriculum needs (Ball \& Garton, 2005) [7]. The academic community also functions in determining the direction of learning with the set objectives, and in fact is an important model of learning 
for the students (Bocala, 2012) [6].

This study uses the reflective theory (Wallace, 1991, 2015) [8] that teacher educators must have existing knowledge and experience related to their field of employment. When undergoing professional training, a teacher educator is able to relate received knowledge with experiential knowledge that is two important sources of professional training. Received knowledge is the knowledge obtained as a result of the teaching and learning, while the experiential knowledge by an individual is a knowledge through their own activity naturally in everyday life. Both of these experiences complement each individual student to become a more meaningful learning experience (Middleton, (2013) [9]. Both these sources of knowledge are, according to Wallace $(1991,2015)$ [8] mutually dependent on enabling teachers to be more ready to carry out their professional tasks. In the context of this study, student engagement depends on the experience and knowledge found in the lecturers. Inculcation of inclusive pedagogy by lecturers in learners at the Institute of Teacher Education (Institut Pendidikan Guru, IPG) influences the application of theory into practice when they first serve as novice teachers later. This study also requires lecturers to undertake are flection on their teaching and learning by relating their knowledge and their experience of inclusive pedagogy with the ability level of the IPG students (Nomme \& Birol, (2014) [10].

\section{Statement of Problem}

Studies have revealed that the occurrences of IP may show a positive relationship with learning outcomes. Unawareness of teachers in schools toward their students' ability levels causes teachers to often conduct teaching and learning based on the planning desired by the learning standards (Florian \& Spratt, 2013) [5]. Studies have shown that teachers in schools often feel that students having the same ability levels are responsive toward the teaching and learning of teachers in the classroom (Hall, Quinn \& Gollnick, 2014; Hardy \& Woodcock, 2015) [11] [12]. Studies also show that teachers introduce teacher-centered, student centered and resource based teaching and learning approaches (MacKenzie \& Ballard, 2015, Petersen, \& Gorman, (2014) [13] [14]. The choice and planning of teachers in determining the approach, technique and activity in any teaching is to achieve desired learning outcomes (Mesquita, Coutinho, De Martin-Silva, Parente, Faria, \& Afonso, (2015) [15]. Nevertheless, many studies found that teachers feel that IP is synonymous with special needs children in school without knowing inclusive pedagogy is a philosophy uniting the student, families, teachers/educators and community members to create a conducive school or social institution (Missildine, Fountain, Summers \& Gosselin, 2013) [16]. The inclusive process will enable students from diverse backgrounds and abilities to gain the same opportunities and access the same teaching/learning through different strategies and techniques.

\section{Objective of Study}

This study aims to explore the literacy of inclusive pedagogy among the aca- 
demic community in the Institut Pendidikan Guru. The focus of the study is in the application of IP in teaching and learning in the classroom. The research question to be answered by the study is

1) To what extent the IP is made the medium of teaching and learning among the lecturers at the Institute of Teacher Education.

2) To what extent the IP strategy significant to the process of teaching and learning.

\section{Methodology}

The research design used depends on the purpose of a study (Maxwell, 2005) [17]. In line with the objective of the study to explore the inclusive pedagogy literacy among the academic community at the Teacher Education Institute (Institut Pendidikan Guru) and its application in the classroom, qualitative methods used in data collection using interviews, observation, and reflection from the sample.

\subsection{Respondents}

Initially, 24 academic lecturers from Institute of Teacher Education were involved in this study consisting of lecturers among those with specializations in specific subjects as shown in Table 1. The samples were chosen among the lecturers at the Institute of Teacher Education through purposive sampling based on their involvement in their major teaching specialization.

The respondents are lecturers who have teaching experience between 8 - 15 years old with an average age of between 45 years. In addition, gender male lecturers were $8(33.3 \%)$ people and the remaining 16 (66.6\%) women were among the lecturers.

\subsection{Data Collection Procedures}

This study used a qualitative data collection approach requiring the researcher to act as the main instrument (Bogdan \& Biklen, 2007; Merriam, 2001) [18] [19]. Data were collected through observations, interviews as well as reflective analysis of the lecturers' teaching and learning.

Table 1. Distribution of respondents.

\begin{tabular}{cc} 
Department & Number of Lecturers \\
\hline Special Education & 3 \\
Language Specialization (Malay Language and English Language) & 6 \\
Music Education & 3 \\
Physical Education & 3 \\
Islamic Education & 3 \\
Visual Arts Education & 3 \\
Sports Science & 3 \\
Total & 24 \\
\hline
\end{tabular}




\subsubsection{Observation}

The data were collected by observations thus giving the researchers opportunity to obtain information directly from the program, process or any matter to be researched in a natural situation (Merriam, 2001) [19]. For this study, the observation protocol (Appendix A) is used as a guide for determining matters to be observed and recorded. In the context of the study, the researcher will carry out observation of the teaching and learning by the lecturer in the classroom.

\subsubsection{Interview}

For this study, interview technique is the source enabling the researcher to know and understand as well as confirm the phenomenon being studied. This technique is a purposive conversation requiring the interviewer to be face to face as individuals or in a group (focus group) with the participants in order to obtain information or clarification regarding some matter.

In the context of the study, interviews were carried out after the respondents (lecturers) had carried out their teaching and learning. Focused interviews were carried out one week before and one week after carrying out teaching and learning. This entailed the researchers to provide stimuli to enable lecturers to do reflection on their teaching and learning. Interviews conducted not less than one hour for each session depending on the saturation data. The respondents were interviewed in focus groups according to their areas of expertise of each study. In this context, the respondents interviewed by the departments that they each consist of those who are in Special Education, Language Skills (Malay Language and English Language), Music Education, Physical Education, Islamic Education, Visual Arts Education and Sports Science.

\subsection{Data Analysis}

As emphasized by Miles and Huberman (1994) [20], analysis begins as soon as the researcher starts the field work. Data collected were analyzed at two levels: analysis during data collection and analysis after data collection. Data analysis in the first phase was carried out simultaneously and continuously when in and outside the field. This meant that the researcher carried out analysis while observations were ongoing. Issues and matters arising and requiring clarification from participants were answered through interviews later. The researcher also had the opportunity to obtain related documents for triangulation. All the collected data were arranged in the form of field notes and audio cassette recordings that needed to undergo the data cleaning stage, data understanding, and analysis to determine the codes and categories.

\section{Findings}

This study is aimed at exploring the IP literacy among the academic community at the Teacher Education Institute by giving focus to the application of IP in teaching and learning. The question to be answered in this study is to what extent inclusive pedagogy is used as the mode of teaching and learning among the 
lecturers at the Institut Pendidikan Guru. This study also tries to explore to what extent the strategy of IP significant in the process of teaching and learning in the classroom context. Responses were analyzed qualitatively to address the research question. Themes of the findings are as follow.

\subsection{Varied Teaching and Learning Approaches to Attract Student Interest and Attention}

The findings of the study show that respondents use inclusive pedagogy strategy as varied teaching and learning approaches to attract student interest and attention. Student centered and resource centered elements formed the core of implementing classroom teaching and learning.

Student centered also known as learner-centered education, broadly encompasses methods of teaching that shift the focus of instruction from the teacher to the student. In original usage, student centered learning aims to develop learner autonomy and independence by putting responsibility for the learning path in the hands of students.

Resource centered elements mean that students use the resources provided to understand the context of teaching and learning in the classroom.

\subsection{Varied Approaches in Teaching and Learning to Ensure Achievement of Course Learning Outcomes}

The findings also show that respondents use varied and multiple approaches in teaching and learning to ensure achievement of Course Learning Outcomes. For this objective, inclusive pedagogy is one of the interdisciplinary modes of delivery. The study also found that respondents were always making effort to encourage and unearth the potential of students in the classroom. They showed awareness of the varied levels of ability and capability of students. This is true of all fields of specialization involved.

\subsection{Encourage Collaborative Problem Solving}

Besides that, the findings also show that respondents stimulate the critical thinking of students, give tasks based on problem solving and encourage collaborative problem solving in classroom teaching and learning. These elements are inculcated by considering the individual differences in ability among the students.

\subsection{Varied Needs and Different Capacities of Student Groups}

The research found that respondents incorporate the element of Inclusive Pedagogy forms one of the teaching media where this pedagogy practice can fulfill the varied needs and different capacities of student groups. Courses such as in Music education, physical education and sports science need to use this kind of approaches as the student's entry point are different from one and another. This is able to create an environment unlimited by student diversity in terms of cognitive level, and social and cultural backgrounds. 


\subsection{Significant Approach}

Research also found that respondents believe that the application of inclusive pedagogy is the significant approach in respect of the capabilities and abilities of students in the classroom. This is because there are students in teacher education institutes of different capabilities. So by introducing this approach, students feel they are able to be equally active in teaching and learning in the classroom.

\section{Discussion}

This study aims to explore literacy pedagogy inclusiveness among lecturers in teacher training institutes. The findings show that the lecturers to practice elements of inclusive pedagogy in teaching and learning in the classroom. The role of the academic community in completing the trainee teachers with the knowledge of pedagogy is important. Teaching and learning strategies are introduced to a variety of supplies for the start of their work as a teacher in the future. Inclusive pedagogy is one of the teaching and learning strategies (Missildine, Fountain, Summers \& Gosselin, 2013) [16].The concept of inclusive pedagogy is to give space and opportunity for all students to be actively involved on the basis of the level of their capacity and capability of each individual. This element is very important in giving confidence to the students to actively participate in classroom-based capability (Jones, 2014; Petersen \& Gorman, 2014) [21], [14]. Therefore, this study was undertaken to explore the extent of the use of inclusive pedagogy in the academic community and hold a significant element in the teaching and learning in the classroom.

Diversity in teaching and learning approaches, especially in introducing an inclusive pedagogy provides a new experience to the trainee teachers. It is well suited for inclusive pedagogy used against students of various levels of ability in particular students of option music, physical education and languages have different levels of basic skills and are suitable they are exposed to these concepts. In addition, those experienced by trainee teachers is likely to be put into practice when they start working as a teacher in the future (Jones, 2014; Missildine, Fountain, Summers \& Gosselin, 2013) [16] [21].

The study also explores significant extent inclusive pedagogy in teaching and learning in teacher education institute. The findings clearly show that the students have the ability and different abilities to each other in class. Thus, by adopting the inclusive pedagogy, lecturers provide the opportunity and the chance for students to feel confident in carrying out the tasks outlined. Inclusive pedagogy is also responsible for the disappearance sparked a spirit of cooperation of students in the classroom. Their sensitivity to different levels of ability, especially when given different level of task and assignments would be a serious boost morale and work together towards the goal of teaching and learning.

Other than that, lecturer sensitivity to different levels of ability among students is also a very important element. This is because, as educators, we should not deny that there are capacity and capability in individual aspect. Thus, a lecturer will become more creative in planning activities and tasks so that all stu- 
dents have the opportunity to taste success based on their ability.

\section{Conclusion}

Exposure to inclusive pedagogy is especially significant among students in teacher training institutes. These elements give the experience and added value is particularly valuable when they are dealing with real situations when they are in place in schools. Inclusive Pedagogy is one of the modes of teaching that helps in optimizing the capabilities of student groups (Milem, 2007), [4]. The practice of Inclusive Pedagogy in the classroom is among the initiatives proposed to achieve the aims of the government in enhancing equity and unity in line with the objectives highlighted in the Malaysia Education Blueprint (MEB) 2013-2025.

\section{Conflict of Interest Declaration}

Authors declare there is no conflict of interests with this study, the authorship and the publication of this paper.

\section{References}

[1] Ministry of Education (2013) Pelan Pembangunan Pendidikan Malaysia 2013-2025. Ministry of Education, Kuala Lumpur.

[2] Cohen, D.K. and Bhatt, M.P. (2012) The Importance of Infrastructure Development to High-Quality Literacy Instruction. The Future of Children, 22, 117-138. https://doi.org/10.1353/foc.2012.0012

[3] Lumpkin, A.L., Achen, R.M. and Dodd, R.K. (2015) Student Presumptions of Active Learning. College Student Journal, 49, 121-133.

[4] Milem, J. (2007) Making Diversity Work on Campus: A Researchbased Perspective. Association of American Colleges and University, Washington DC.

[5] Florian, L. and Spratt, J. (2013) Enacting Inclusion: A Framework for Interrogating Inclusive Practice. European Journal of Special Needs Education, 28, 119-135. https://doi.org/10.1080/08856257.2013.778111

[6] Bocala, C. (2012) Strategic Management of Human Capital in Education: Improving Instructional Practice and Student Learning in School. Harvard Educational Review, 82, 123-141.

[7] Ball, A.L. and Garton, B.L. (2005) Modeling Higher Order Thinking: The Alignment between Objectives, Classroom Discourses, and Assessment. Journal of Agricultural Education, 46, 58-69. https://doi.org/10.5032/jae.2005.02058

[8] Wallace, M.J. (1991) Training Foreign Language Teachers: A Reflective Approach. Cambridge University Press, Cambridge.

[9] Middleton, R. (2013) Active Learning and Leadership in an Undergraduate Curriculum: How Effective Is It for Student Learning and Transition to Practice? Nurse Education in Practice, 13, 83-88. https://doi.org/10.1016/j.nepr.2012.07.012

[10] Nomme, K. and Birol, G. (2014) Course Redesign. An Evidence Based Approach. The CanadianJournal for the Scholarship of Teaching and Learning, 5, Article 2. https://doi.org/10.5206/cjsotl-rcacea.2014.1.2

[11] Hall, G.E., Quinn, L.F. and Gollnick, D.M. (2014) Introduction to Teaching Making a Difference in Student Learning. Sage, Thousand Oaks.

[12] Hardy, I. and Woodcock, S. (2015) Inclusive Education Policies: Discourses of Dif- 
ference, Diversity, and Deficit. International Journal of Inclusive Education, 19, 141-164. https://doi.org/10.1080/13603116.2014.908965

[13] MacKenzie, L. and Ballard, K. (2015) Can Using Individual Online Interactive Activities Enhance Exam Results? Journal of Online Learning and Teaching, 11, 262.

[14] Petersen, C.I. and Gorman, K.S. (2014) Strategies to Address Common Challenges When Teaching in an Active Learning Classroom. New Directions for Teaching and Learning, 2014, 63-70. https://doi.org/10.1002/tl.20086

[15] Mesquita, I., Coutinho, P., De Martin-Silva, L., Parente, B., Faria, M. and Afonso, J. (2015) The Value of Indirect Teaching Strategies in Enhancing Student-Coaches' Learning Engagement. Journal of Sports Science and Medicine, 14, 657-668.

[16] Missildine, K., Fountain, R., Summers, L. and Gosselin, K. (2013) Flipping the Classroom to Improve Student Performance and Satisfaction. Journal of Nursing Education, 52, 597-599. https://doi.org/10.3928/01484834-20130919-03

[17] Maxwell, J.A. (2005) Qualitative Research Design: An Interactive Approach. 2nd Edition, Sage, Thousand Oaks.

[18] Bogdan, R.C. and Biklen, S.K. (2007) Qualitative Research for Education: An Introduction to Theory and Methods. 5th Edition, Allyn \& Bacon, Boston.

[19] Merriam, S.B. (2001) Qualitative Research and Case Study Applications in Education. Jossey-Bass Publishers, San Francisco.

[20] Miles, M.B. and Huberman, A.M. (1994) Qualitative Data Analysis: An Expanded Sourcebook. 2nd Edition, Sage, Thousand Oaks.

[21] Jones, P. (2014) Bringing Insider Perspectives into Inclusive Teacher Learning: Potentials and Challenges for Educational Professionals. Routledge, New York.

\section{Submit or recommend next manuscript to SCIRP and we will provide best} service for you:

Accepting pre-submission inquiries through Email, Facebook, LinkedIn, Twitter, etc. A wide selection of journals (inclusive of 9 subjects, more than 200 journals)

Providing 24-hour high-quality service

User-friendly online submission system

Fair and swift peer-review system

Efficient typesetting and proofreading procedure

Display of the result of downloads and visits, as well as the number of cited articles

Maximum dissemination of your research work

Submit your manuscript at: http://papersubmission.scirp.org/

Or contact jss@scirp.org 